\title{
Judicial Mafia in Criminal Justice System and Its Countermeasure
}

\author{
Anggun Paramarta \\ Master of Law of Universitas Diponegoro \\ Jl. Imam Bardjo No. 1, Pleburan, Semarang Selatan \\ anggunparamarta@gmail.com
}

\begin{abstract}
As a way of seeking justice, the judicial mafia is an outlaw action in the criminal justice process. Thus, it leads to judicial failure that damages the independence and impartiality of the court. That is because legal engineering carried out by judicial mafia syndicate violates the principles of due process of law in the criminal justice process. The current criminal justice process shows the blurring orientation of law enforcers in an effort to uphold the law and justice where the main purpose of litigation is not to uphold the law and justice, but to winning the cases. Therefore, it is necessary to overcome judicial mafia practices in the criminal justice system. The author uses normative juridical research method. The results of the study show that the cause of the flourishing judicial mafia in Indonesia's criminal justice system is because law enforcement officers are not able to uphold their oaths of office. Therefore, overcoming judicial mafia practices can be done by penal or non-penal.
\end{abstract}

Keywords: Judicial Mafia; Criminal Justice System; Countermeasures

\section{A. INTRODUCTION}

The ideal function of the court as a law enforcement institution is currently experiencing a down turn caused by manipulation, discrimination and injustice as the result of judicial corruption that is well-known as judicial mafia (Daradono, 2007). Judicial mafia is a fiasco of the court as a means to seek for justice and has become deviant pattern in the process of criminal justice.

Judicial mafia is a group of advocates governing the judicial processes who can waive the lawsuit of the defendant when he or she provides appropriate bribe (Yuwono, 2010). However, other statement exposes that judicial mafia is not a mere deviant process occurred in the court where judges have the power to adjudge, but widely covers the investigation process carried out by police officers, prosecutors, advocates and others who in his acts influence the justice (Indah S., 2011). Some people's and the apparatuse's moral damage generate the higher potential of judicial mafia to emerge. Those who deal with laws believe that laws can be manipulated accordingly. Those who deal with police officers obviously expect to be found not guilty. Moreover, they also want the lightest sentence when they have been processed by the prosecutor.

Judicial mafia practice is an act against the law that damages the joints of independence and neutrality of the court, because legal engineering carried out by 
the judicial mafia syndicate violates the principles of due process of law in the criminal justice process.

The process of criminal justice is carried out based on transactional consideration between the party of capital power and one of public power or the law enforcer, resulting injustice and discrimination in criminal law enforcement. Such practice becomes a bad record for the court for defiling the court's integrity, even there are some judges who set themselves in profit-driven industry or a business form which is directed to obtain profit (Said, 2011). If the judge's decision has been contaminated with materialistic interest, the decision will not side with justice. Therefore, people distrust the court. Their distrust to the court causes vigilante and insult to the court (obstraction of Justice) (Mardin, 2007).

The criminal justice is distorted by the rationale of economic transactional. The practice of judicial mafia becomes more creative in engineering the legal proceeding. The defence of criminal cases is no longer built up on logical legal argumentation but based on lobby power and approaching to various parties which are the investigators, public prosecutors or judges to win the case, alleviate criminal sanction, and to free the accused from the charge.

The law which is well made to serve the people will mean nothing if it is not supported by good mentality of the law enforcers. It then heard sarcasm insinuation in the world of law "give me a good judge, good prosecutor, good cops, even without good constitution, the result will be the best ever produced in this country" (Mardin, 2007).

Based on the elaboration of the background above, the further issues that will be discussed are: (1) What is the cause of judicial mafia in the criminal justice system and (2) how is the prevention effort of judicial mafia in a court case?

\section{B. RESEARCH METHOD}

The method of this research used normative legal research which is a literature study. Literature study is needed to collect necessary legal materials such as primary legal material like the criminal procedural law, Government regulation No. 27 of 1983 concerning the implementation of the criminal procedural law, Law No. 48 of 2009 concerning judicial power, and Law No. 5 of 2004 jo Law No. 3 of 2009 concerning the supreme court. Secondary legal materials are like books, legal scientific work, and other written materials that can be used to give explanation from some terminologies used in this research.

\section{DISCUSSION AND ANALYSIS}

\section{The Cause of Judicial Mafia in the Criminal Justice System}

According to Barda Nawawi Arief, the essence of judicial system is a process of law enforcement. The process of the court is essentially identical with the judicial power system because it is basically a power or authority to enforce the law. When 
it is focused on the field of criminal law, it can be said that criminal judicial law is essentially the criminal law enforcement system which is also identical with the judicial power system in the field of criminal law (Arief, 2009).

Based on Muladi, criminal justice system has to be seen as the network of courts and tribunals which deals with criminal law and its enforcement. It contains systematic motion from its supporting subsystems such as police, attorney, court and correctional institutions as a whole. The system also involves humans both as subject and object of the law. Therefore, the main requirement of rational criminal justice system is by understanding and considering the impact to humans both in the system framework and outside the system (Jaya, n.d.).

As a system, criminal justice system is basically an open system which means that its attempt to achieve the goals (short term: rationale, mid-terms: crime prevention, long-term: social welfare) is influenced by social environment and humanity life aspects. It is then resulting in the experience of interface in the process of criminal justice system with the environmental levels of: social, economy, politic, education and technology as well as subsystems from the criminal justice system (Jaya, n.d.). Each operation of criminal justice system in every step (investigation, prosecution, examination in the court, from district court to the supreme court, and the stage of the court execution) has the possibility to get 'dirty' (Arief, 2014). The term of 'dirty' is well known as judicial mafia.

The judicial mafia exists because the bureaucracy is convoluted and not transparent. As Charles R Ashman said, "American justice is choking on judicial pollution. The following cases are documented proof that it is a question of occasional corruption, but a pattern of conflicts of interest, chronic bribery, profound abuse of office, loathsome nepotism, infamous sexual perversions and pernicious payoffs" (Ashman, 1973). There are often deviations in the practice of the criminal justice system that lead to the emergence of judicial mafias. The following are the causes of the emergence of a judicial mafia (Wiriadinata, 2010):

a. Weakness of the legislation system that governs criminal procedural law.

b. Weakness of law enforcement officers. The weakness of investigators, prosecutors and judges in law enforcement can be seen as indicated by the lack of integrity of the law enforcers. Those who should avoid illegal actions by not committing crimes have apparently committed many crimes such as bribery, gratification and corruption. The low level of honesty, obedience, professionalism of law enforcement officers is caused by various reasons.

c. Weakness of legal awareness of the community. In the condition of a good legal system and good law enforcement officers, the law will be enforced properly if it is supported by the community legal awareness. In fact, the legal awareness of Indonesian people is still low. This can be proven from the violation of law by the people who arrived at the court due to the lack 
of legal awareness. One of the most prominent examples is the habit of people giving facilitation payments and bribes to the officers.

d. The lack of example in the implementation of the criminal justice process is influenced by the daily habits of the law officials and bureaucrats.

The judicial mafia is basically caused by the influence of money, the influence of nepotism, political influence and other influences. Because the judicial mafia is caused and influenced by money, the justice mafia cannot be separated from corruption in the criminal justice system. Corruption in the criminal justice system is more commonly known as judicial corruption (Danilet, 2009), "judicial corruption is not an act through the justice system that is negatively influenced that affects the impartiality of judicial proceedings for the purpose of obtaining illegitimate benefits for themselves or other persons"

In general, the practice of judicial mafia in the court includes: (1) request for money. In this case, the lawyer must prepare extra money for the case registration section; (2) the determination of the panel of judges is carried out on its own or by requesting a court clerk prosecutor; (3) had been prior coordination of the demands of the Public Prosecutor which led to the verdict of the judges, there were bargaining negotiations between judges, prosecutors, and lawyers about the penalties and money to be paid.

\section{a. The judicial mafia practice at the investigation level}

A case related to the judicial mafia that occurred during the investigation phase was the case of Bank Indonesia Liquidity Assistance (i.e. Bantuan Likuiditas Bank Indonesia [BLBI]) involving Urip Tri Gunawan and Artalyta Suryani and also a corruption case in the level of investigation in the case of suspects Bibit Samad Ryanto and Chandra M Hamzah involving brokers Anggodo Widjoyo's case (Rayenda, 2017).

At this stage, the judicial mafia usually offers articles that can alleviate the examinee. If the examinee does not respond or does not heed the offer of the judicial mafia, the process will proceed with full of intimidation and will make the examinee face a frightening investigation process. In fact, the judicial mafia also uses promising mode that can manipulate the case by offering light articles in ensnaring the criminal case that has been carried out by the examinee. Judicial mafia perpetrators are able to offer justice seekers, suspects to eliminate evidence, so that there will be lack of evidence to proof the guilt, so that in time, being examined will escape legal entanglement. This is a form of case engineering carried out by the law enforcement officials that cannot be allowed to continue. Since decades ago, incidents of criminal case engineering have occurred many times, even afflicting the public and have become a public spotlight reaping criticism from them. Unfortunately, such practices still continue to occur today. 
After investigators carried out a series of actions to uncover criminal offense with sufficient evidence support, investigators at the police level can improve the status from examinee to suspect. In this process, the judicial mafia tried their best to lobby the investigators so that the suspects were not arrested. Investigators can arrest or not arrest the suspects in accordance with Article 20 paragraph (1) of the Criminal Procedure Code. On the basis of these provisions, investigators can abuse the authority to arrest or not arrest the suspects because it is the investigator's absolute authority.

The judicial mafia influences individual investigators in every way to prevent the suspect from being detained. Judicial mafia power in manipulating cases is very large, so that the legal apparatus cannot do much other than to obey all the wishes of the judicial mafia.

\section{b. Practice the judicial mafia at the prosecutor's level}

An example of a judicial mafia at the prosecution stage was the case on behalf of Achmad Djunaedi (Former Director of Jamsostek) who was sentenced to 8 (eight) years in prison. The case began when Achmad Djunaedi was sentenced to 8 years in prison as attorney of General's Office and Prosecutors Office of South Jakarta expressed an appeal because the judge's verdict was far lower than the demands: 16 years. Achmad Djunaedi accused 5 members of the prosecutor's team: Heru Chaerudin, Pantono, MZ Idris, Burdju Ronni, and Cecep, of extortion. The AGO appointed Burdju and Cecep as suspects in extortion cases. The suspect was charged with Article 12 A and Article 12 E of Law No. 31 of 1999 concerning Eradication of Corruption Crime with the threat of 10 and 15 years in prison.

The judicial mafia in the prosecutor level includes (Rayenda, 2017):

1) Extortion, extended investigation to negotiate facilitating payment, intentional summons without the status of "witness" or "suspect", at the end will be asked for money so that the status is not a suspect.

2) Status negotiations, changing the status of suspect is a bargaining tool

3) Releasing the suspect, through a letter of termination of investigation intentionally making an obscure libel so that the defendant is acquitted

4) The embezzlement, the case file is stopped if it gives a sum of money. When handed over to the prosecutor's office, the police said "there is already someone taking care", so that it was not recorded in the register

5) Case negotiations, the process of inquiry being delayed is a sign that the suspect's family is meeting with the prosecutor. It can involve case brokers from the prosecutor's office, children of officials or attorney partners. The severity of the indictment is a bargaining tool 
6) Reducing demands, criminal charges can be alleviated if the defendant gives some money. The Investigation Report was leaked during the investigation. The alleged article can also be traded.

\section{c. Practice of the Judicial Mafia at the Judge's Decision Level}

The example for this case is the case of Abdullah Puteh who bribed Ramadhan Rizal (Registrar of Jakarta High Court), Tengku Syaifuddin Popon (Lawyer), and M. Sholeh (Registrar of Jakarta High Court). Ramadhan Rizal was sentenced to 2 years 6 months on November 18, 2005, Tengku Syaifuddin Popon was sentenced to 2 years 3 months on November 18, 2005, M. Sholeh was sentenced to 2 years 6 months on November 18, 2005.

The practice of the judicial mafia at this level can be carried out with the judge giving an unfair decision, for example by giving a criminal verdict and or a fine lower than what has been indicted by the public prosecutor. The negative impact of the judge's unfair decision cannot be known because it is God's secret. In contrast to the Law which threatens with harsh sanctions, the threat of sanctions can be known through the formulation of the law. Unfortunately, humans do not realize that God's sanctions are harder although it is unkown when.

Judges who stand firm will never falter on the seduction of the judicial mafia because the judge is guided by Article 3 paragraph (2) of Law Number 48 of 2009 concerning Judicial Power which reads: "Any interference in judicial matters by other parties outside the judicial authority is "prohibited", except in matters as referred to in the 1945 Constitution of the Republic of Indonesia." A judge, before carrying out his position as a judge, has been sworn as stipulated in Article 29 of Act Number 48 of 2009 concerning Judicial Power.

The practice of the judicial mafia in general uses and disguises "legal authority/power" as a pretext to practice bribery. The holders of judicial power, under the pretext of free and independent judicial power, in the closure of legal processes, commit legal deviations exchanged for personal material benefits (Wijoyanto, 2007). As a result of judicial corruption, the authority of the judiciary falls, as stated by Cumaraswani who concluded that judicial corruption in Indonesia is one of the worst in the world, which Mexico may only equal, a country whose majority of its people are not surprised at all by the phenomenon of judicial corruption (Said, 2011).

The disclosure of several cases of bribery in judicial institutions involving the ranks of law enforcement in the judicial process as a form of judicial corruption has become a turning point and anomaly in criminal justice reform aimed at strengthening the principle of court independence. Judicial reform has substantially succeeded in placing the judiciary as an independent judicial authority with the design of a one-stop system, with the peak of judicial power in the Supreme Court. This single roof law enforcement system conceptually guarantees "independent 
judicial power", apart from interference from extra-judicial powers. Judicial Corruption involving law enforcers has hampered the pace of judicial reform in efforts to reform the judicial institution, undermined the independence and impartiality of the court, and reduced the level of public trust in the judiciary.

\section{Efforts to Overcome Judicial Mafia in the Criminal Justice Process}

According to Barda Nawawi Arief, efforts to eradicate the judicial mafia is essentially an effort to restore people's trust and respect to the justice system. Community's trust and respect are part of the quality of life and sustainable development. The loss of trust and respect of the society will have an impact on the deterioration of quality of life in various fields (social, political, economic, legal) and damage to sustainable development programs (Arief, 2014). Therefore, the efforts to prevent and eradicate the judicial mafia are the top priority in the renewal of the criminal justice system. This is in accordance with what Cristi Danilet said:

"This is a priority objective in a system of reform, in the broader context of the national level to fight against the phenomenon. Justice corruption may affect the most important social values, among other things, the other things, the prosecution and bringing to justice of corruption offenses" (Danilet, 2009).

Criminal justice is an important part of crime prevention efforts through the means of criminal law. Criminal justice works in an integrated criminal law enforcement system that focuses on the integration of the system so that it is commonly called the Criminal Justice System. The criminal justice system is made integrated so that the judicial process runs effectively and efficiently, supporting each other between law enforcers in finding the law and applying accuracy to ensure the satisfaction of justice seekers in the awareness of the legal reality of society (Hafrida, 2008).

If criminal justice is understood from the aspect of the legal system approach, the operation of criminal justice is highly dependent on the synchronization and harmonization of the components of criminal justice, namely the subsystem of investigation, prosecution, court, and implementation of court decisions, namely Penitentiary. The practice of the judicial mafia is essentially a systematic act that damages the system in criminal justice. Damage to the criminal justice system basically can be derived from procedural systems and value systems. These two components will collapse if one experiences a destructive attack. The behaviour of law enforcers who accept bribes is an act of damaging the legal culture component. As a result, the law enforcers ignore good judicial principles and damage the standardized interaction system. What happens next is the chaotic enforcement of criminal law. Law enforcers involved in the court mafia exchange legal authority with material benefits.

The criminal justice system is often interpreted narrowly as a court system that administers justice in the name of the state or as a mechanism to resolve a case or dispute. In a narrow sense, criminal justice only sees structural aspects and only 
sees aspects of the power of judging or resolving cases. Criminal justice as a system includes two aspects, namely aspects of institutional structure involving several law enforcement agencies and aspects of value, namely the principles of criminal law enforcement which are covered by due process of law. Interaction between the law enforcement agencies in the mechanism of the judicial process covers the chain of authority of the criminal justice system. Conceptually, the core and meaning of law enforcement lie in the activities of harmonizing the relationships of values outlined in the principles that are solid and manifested, as well as acting as a series of final stages of value translation, to create, maintain and maintain life's social peace (Nugroho, 2007)(Soerjono Soekanto, 2014; 5).

Crime prevention is a complicated problem faced by every country. Crime arises and develops along with the progress of society. Various efforts have been made by each country to overcome the emergence of crimes even if possible eliminated. Crime prevention efforts can be broadly divided into 2 (two), namely through the "penal" line (criminal law) and through the "non-penal" line (Arief, 2011):

\section{a. Efforts to Overcome Judicial Mafia Through Penal Means}

This category is meant to take legal action to those who act against justice thrugh the name of judicial mafia within the code of criminal law itself. Eradicating the judicial mafia by building legal officers who are not tempted by money is very difficult. Progressive and responsive people are needed. People who are progressive and responsive must also be supported by moral and mental as a reformer of the paradigm in law.

According to G. P. Hoefnagels, crime prevention efforts can be pursued by (Arief, 2011):

1) The application of criminal law

2) Prevention without punishment

3) Persuading people thougts about the crimes and its sanctions through mass media.

Disabling the judicial mafia is hardly reached by the law, that because of several factors as follows (Gunakaya, 2010):

1) The perpetrators often have high social, political, economic or position status.

2) The perpetrators are judicial officers who will investigate or prosecute or try cases

3) Creating conditions that resemble the deviant acts in such way that only they and a few of their surroundings know

4) The people's unwillingly within the community to report their crima because they have received a share of money from the results of judicial corruption. 
The handling or eradication of judicial mafia through penal process, in my opinion, is currently only possible by classifying acts or crimes committed by the perpetrators as corruption offenses. By classifying criminal acts committed by perpetrators as corruption offenses, then efforts to overcome or eradicate the judicial mafia can be resolved through penal procedure.

\section{b. Efforts to Overcome Judicial Mafia with Non-Penal Facilities}

Crime prevention efforts with non-penal means focuses more on prevention before the crime occurred. The main goal is to deal with the conducive factors that cause the crime. Conducive factors are centred on social problems or social conditions that can directly or indirectly cause or foster crime (Arief, 2011).

The $6^{\text {th }}$ UN Congress in 1980 in Caracas, Venezuela on "The Prevention of Crime and Treatment of Offenders" confirms the following (Arief, 2011):

1) The crime problem impedes progress towards the attainment of an acceptable quality of life for all people.

2) Crime prevention strategies should be based upon the elimination of causes and condition giving rise to crime

3) The main causes of crime in many countries are social inequality, racial and national discrimination, low standard of living, unemployment and illeteracy among broad sections of the popolation.

The Guiding Principles produced by the $7^{\text {th }}$ UN Congress also emphasized that, "policies regarding crime prevention and criminal justice must consider structural causes, including the causes of socioeconomic injustices, where crime is often only a symptom" (Arief, 2011).

The Resolution No.3 of The $6^{\text {th }}$ Congress of 1980, regarding "Effective Measures to Prevent Crime" considers that (Arief, 2011):

1) Crime prevention is dependent on man himself

2) Crime prevention strategies should be based on exalting the spirit of man and reinforcing his faith in his ability to do good

The use of non-penal in overcoming the judicial mafia is also needed in addition to the penal system. That is because the effectiveness of the penal is still doubtful or at least it is not yet known how far the influence. The non-penal can be done through increasing public awareness of the importance of monitoring and reporting on the performance of law enforcement officers.

Community participation is very much needed in overcoming the judicial mafia. The role of community is focused on an observation of whether the process is in accordance with the standards and whether the results of the process have met the quality standard that has been established in the system by theinstitution. 
The monitoring can be carried out in the control of the trial process and before the trial process (i.e. when an examination is carried out at the police and prosecutor's level). Early monitoring can provide more complete and comprehensive information on systematic and planned deviations that can be a supporting information in the examination process.

The efforts to tackle the judicial mafia can also be done by reviewing the supervision or control system owned by the Supreme Court. According to the Law No. 5 of 2004 in conjunction with the Law No. 3 of 2009 concerning the Supreme Court, the Supreme Court only has the supervisory authority over the judges (Article 32), legal counsel and notaries (Article 36). According to the Article 24 of the Indonesia's Constitution "judicial power is carried out by the Supreme Court", then the Supreme Court should not only function to oversee the law enforcement carried out by the judiciary but also oversee the entire law enforcement process from the stage of investigation, prosecution and verdict (Arief, 2014).

\section{The Barring Factors of the Judicial Mafia Prevention in the Criminal Justice System}

In general, the factors that influence law enforcement are the legal factors themselves, law enforcement factors, infrastructure, community factors, and cultural factors of the community. In addition, the effectiveness of the law enforcement is always influenced by the things such as:

\section{a. Supporting Infrastructure Facilities and Infrastructure}

Good law enforcers are the key to good law enforcement. Even though a country has good law and society but if it does not support by good law enforcement, the process of law enforcement in that country will be chaotic. That explains the dishonest behaviour of law enforcers which have shown quite a lot in the practice of law enforcement in Indonesia. The Criminal Procedure Code affirms that the law enforcement process in general is the subjective domain of the law enforcement, the police, the prosecutors and the judges. Whether or not someone is completely wrong is their absolute authority to judge. Even though a million Indonesians consider someone innocent, the police, the prosecutors and the judges ultimately determine whether the person is guilty or not. Even worse, if law enforcement is carried out on the basis of certain interests that are commonly referred to as public politicization in law enforcement.

\section{b. Professionalism of Law Enforcement Officials}

The principle of criminal law in Indonesia is the principle of legality or principle of Nullum delictum noella poena sine praevia lege poenali, which means that each act cannot be convicted before the act is regulated in the prevailing laws and regulations. The legal substance in the form of legislative material should be extracted from the values that live in the community so that there will be no contradiction between the applicable law and the values of society. The legal 
structure is built by the community based on a character of the legal culture of society that should support the performance of the legal structure, and the culture of law will be in line with the substance and legal structure.

\section{c. Culture of Law and Society}

The judicial mafia in the criminal justice system is rife due to lack of public awareness and participation in monitoring the performance of law enforcement officials. The community has confidence that if the case has been brought to the court, then the law enforcement officers will carry out justice processes fairly and objectively and will not be influenced by material benefits. This way of thinking is what makes people feel that there will be no need to supervise the law enforcement officers.

\section{CONCLUSION}

Judicial Mafia is emerging in the criminal justice system in Indonesia because law enforcement officials are unable to uphold their oaths of office, hold public trust, and lack the morale of law enforcers which causes the law enforcers to be persuaded, tempted by the benefits of matei (money).

Efforts to tackle the judicial mafia in the criminal justice system in Indonesia can be done by using the means of penal and non-penal process. The penal concept is by charging the law enforcement officials who have committed judicial mafia crimes through criminal law, while non-penal is by increasing the public awareness of the importance of monitoring and reporting on the performance of law enforcement officers.

\section{REFERENCES}

Arief, B. N. (2009). Reformasi Sistem Peradilan (Sistem Penegakan Hukum) di Indonesia. Semarang: Universitas Diponegoro.

Arief, B. N. (2011). Bunga Rampai Kebijakan Hukum Pidana "Perkembangan Penyusunan Konsep KUHP Baru." Jakarta: Kencana.

Arief, B. N. (2014). Masalah Penegakan Hukum dan Kebijakan Hukum Pidana dalam Penanggulangan Kejahatan. Jakarta: Prenamedia Group.

Ashman, C. R. (1973). The Finest Judge Money Can Buy. Los Angels: Nash Publishing.

Danilet, C. (2009). Corruption and Anti-Corruption in the Justice System. Bucharest: Editura C.H. Beck.

Daradono, D. (2007). Uang, Ideologi, Jabatan dalam Mafia Peradilan, Reduksi terhadap The Political. Renai, Jurnal Kajian Politik Lokal Dan Studi Humanoria, $8(2)$.

Gunakaya, W. (2010). Pemberantasan Mafia Peradilan Dengan Pemberdayaan "Gaya Sentrifugal" dan "Sentripetal" Hukum Dalam Penegakan Supremasi Hukum (Suatu Kontemplasi Refleksif). Jurnal Wawasan Hukum, 23(02), 167-197.

Hafrida. (2008). Sinkronisasi Antar Lembaga Penegak Hukum dalm Mewujudkan Sistem Peradilan Pidana yang Terpadu. Jurnal Hukum Forum Cendekia, 18(2).

Indah S., C. M. (2011). Pemberantasan Mafia Peradilan Menuju Reformasi Hukum di Indonesia. $M M H, 40(1), 60-65$.

Jaya, N. S. P. (n.d.). Sistem Peradilan Pidana (Criminal Justice System). 
Mardin, N. (2007). Makna Kepala Putusan Pengadilan: Keadilan Berdasarkan Ketuhanan Yang Maha Esa (Tinjauan Rechtphilosopie). Jurnal Hukum Aktualita, 2(3).

Nugroho, H. (2007). Optimalisasi Penegakan Hukum dalam Penanggulangan Kejahatan Global di Indonesia. Jurnal Media Hukum, 17(4).

Rayenda, R. S. (2017). Reformasi sistem peradilan dalam rangka pemberantasan mafia peradilan. Bandung.

Said, N. A. (2011). Rekonstruksi Pertanggungjawaban Pidana Terhadap Tindak Pidana Korupsi APBD yang Dilakukan Oleh Anggota DPRD. Jurnal Dinamika HUkum, 11, 135-149.

Wijoyanto, B. (2007). Harmonisasi Peran Penegak Hukum dalam Pemberantasan Korupsi. Jurnal Legislasi Indonesia, 4(1).

Wiriadinata, W. (2010). Masalah Mafia Peradilan dan Korupsi di Indonesia. Jurnal Ilmu Hukum Syiar Hukum, 12(1), 49-61.

Yuwono, I. D. (2010). Kisah Para Markus (Makelar Kasus). Jakarta: Media Pressindo. 